\title{
PENYAKIT KUSTA DI BANGKALAN PADA ABAD KE-20
}

\author{
Dina Dwikurniarini, M.Hum* \\ Ita Mutiara Dewi, M.Si**
}

\begin{abstract}
This article discusses leprosy disease that has ever spread in Indonesia in the 20th century, especially in Bangkalan, Madura. This article attempts to uncover factors contributing to the development of the leprosy epidemic in Bangkalan, Madura and to know how the Dutch East Indies colonial government in tackling the leprosy epidemic in Madura. Bangkalan geographical factors with a hot climate, causing lack of access to clean water for hygiene and sanitation for the community. In addition Bangkalan population density is quite high, so the plague of leprosy easily spread. The Dutch East Indies colonial government tried to impose various policies such as health propaganda in tackling the disease.
\end{abstract}

Key words: History, Health, Hindia Belanda

\begin{abstract}
Abstrak
Artikel ini membahas tentang penyakit kusta yang pernah mewabah di Indonesia pada Abad ke-20, terutama di wilayah Bangkalan, Madura. Artikel ini berusaha mengungkap faktor-faktor yang berkontribusi terhadap perkembangan wabah penyakit kusta di Bangkalan, Madura dan mengetahui cara pemerintah kolonial Hindia Belanda dalam menanggulani wabah kusta di Madura. Faktor geografis Bangkalan dengan iklim yang panas, menyebabkan kurang tersedianya akses air bersih untuk higieni dan sanitasi bagi masyarakat. Selain itu tingkat kepadatan penduduk Bangkalan cukup tinggi, sehingga wabah kusta mudah menyebar. Pemerintah Kolonial Hindia Belanda berusaha memberlakukan berbagai kebijakan seperti propaganda kesehatan dalam menanggulangi penyakit tersebut.
\end{abstract}

Kata kunci: Sejarah, Kesehatan, Hindia Belanda

\section{A. Pendahuluan}

Aspek kesehatan merupakan salah satu aspek penting dalam menentukan jumlah penduduk. Tingginya angka mortalitas pada abad ke-19 dan awal abad ke-20 di Jawa misalnya, tidak dapat dijelaskan tanpa menghubungkan permasalahan tersebut dengan faktor kesehatan masyarakat. Perilaku dan kebiasaan masyarakat, kondisi perekonomian dan politik, pengaruh iklim dan lingkungan serta keterbatasan pelayanan kesehatan pada masa itu merupakan kombinasi faktor-faktor yang menyebabkan munculnya berbagai macam epidemi penyakit menular yang menelan banyak korban. Pada awal abad ke-19 di Jawa, beberapa epidemi penyakit lebih banyak yang menyebar di lingkup lokal dan regional. Penyakit-penyakit tersebut antara lain kolera, disentri, demam (kemungkinan malaria atau tipus), kusta, dan cacar. ${ }^{1}$

Kusta merupakan salah satu wabah atau epidemi yang menjadi salah satu fokus perhatian kesehatan pada masa kolonial, abad ke-20. Timbulnya wabah ini memberi gambaran buruknya kondisi kesehatan penduduk. Berbagai faktor yang mempengaruhi kondisi masyarakat meliputi nutrisi yang tidak baik, kurangnya kebersihan air, kebersihan lingkungan maupun pelayanan

\footnotetext{
* Staf Pengajar di Program Studi Ilmu Sejarah FIS UNY

** Staf Pengajar di Program Studi Ilmu Sejarah FIS UNY

1 Baha'uddin, "Dari Mantri hingga Dokter Jawa: Studi Kebijakan Pemerintah Kolonial dalam Penanganan Penyakit Cacar Di Jawa Abad XIX-XX”, Humaniora. Vol.18 No.3 (Yogyakarta, 2006), hlm.286.
} 
kesehatan. Gambaran demikian umumnya terjadi di negara-negara miskin dengan jumlah penduduk yang besar seperti halnya Jawa masa kolonial.

Penyakit kusta masuk ke Hindia Belanda bersamaan dengan kedatangan orang-orang India yang datang untuk berdagang, selain itu ada anggapan lain bahwa orang Cina yang sejak dulu terkena penyakit kusta, sehingga ikut menyebarkannya ke wilayah Hindia Belanda. Impor budak yang dilakukan pada masa kolonial ikut berperan dalam menyebarkan penyakit ini. ${ }^{2}$ Prediksi yang lain menyebutkan keberadaan kusta di Indonesia diperkirakan masuk melalui aliran tahanan yang dibawa sipir yang dikuasai Portugis ke Batavia. Oleh karenanya kusta telah menjadi permasalahan pada awal kedatangan Belanda di Nusantara dan mencapai puncaknya pada akhir kekuasaan Belanda. ${ }^{3}$

Penyakit kusta di Hindia Belanda diketahui sejak abad ke-17, ditandai dengan adanya tempat rehabilitasi di Batavia yang ditangani oleh dokter Willian Ten Rhijne. Pertama kali, pusat rehabilitasi kusta berada di wilayah Angke, di luar tembok Batavia, namun kemudian dipindah ke teluk Purmerend oleh pemerintah. Penyakit kusta berkaitan erat dengan kondisi lingkungan. Tidak mengherankan jika penyakit kusta lebih banyak menjangkiti wilayah dengan perekonomian rendah dan sedang berkembang.

Persebaran penyakit kusta di Hindia Belanda terjadi di wilayah Jawa, Sumatera, Kalimantan, Sulawesi, Maluku hingga Papua. Jumlah terbesar terjadi di Jawa Timur dan terbanyak di Bangkalan, Madura. Kondisi itu terutama disebabkan oleh keadaan geografis dan demografis Bangkalan yang padat dan kumuh.

Pada tahun 1934 angka kematian yang disebabkan oleh penyakit Kusta meningkat tajam, salah satunya terjadi di wilayah kabupaten (regentschap) Bangkalan. Pola penyebaran penyakit ini tidak terlepas dari kondisi geografis dan demografi wilayah tersebut. Wabah penyakit kusta di Hindia-Belanda mencapai angka tertinggi pada tahun 1936. Kabupaten Bangkalan merupakan daerah yang penduduknya paling banyak terjangkit penyakit kusta.

\section{B. Faktor-faktor Penyebab Wabah Kusta Di Bangkalan, Madura}

Penyebaran penyakit kusta di Bangkalan memiliki pola yang sama dengan pola penyebaran penyakit di wilayah lain, yaitu dengan melalui mobilitas penduduk. Sudah sejak lama, masyarakat Madura dikenal sebagai masyarakat yang gemar merantau. Hal itu dapat dibuktikan dengan adanya desa-desa orang Madura di pojok timur karesidenan-karesidenan di Jawa, 25 desa di Pasuruan, 3 desa di Probolinggo, 22 desa di Puger (Jember) dan 1 desa di Panarukan. ${ }^{4}$ Orang Madura yang merantau ke Jawa rata-rata akan pulang kembali saat musim pembuatan garam dan panen tembakau. Dengan mobilitas demikian, kemungkinan besar penularan penyakit kusta menjadi lebih tinggi di Madura. Selain faktor mobilitas penduduk,

\footnotetext{
${ }^{2}$ Peter Boomgaard "Syphilis, Gonorrhoea, Leprosy and Yaws in Indonesian Archipelago, 1500-1950". MANUSYA: Jurnal of Humanities, Special Issue No.14.2007, hlm.26.

${ }^{3}$ Marwali Harahap, Ilmu Penyakit Kulit, (Jakarta: Hipokrates, 1998), hlm. 261.

${ }_{4}$ Muh.Syamsuddin, Agama, Migrasi dan Orang Madura. Aplikasia, Jurnal Aplikasia Ilmu-ilmu Agama, Vol VIII, No.2, Desember (Yogyakarta:UIN,2007) hlm.163.
} 
banyak faktor-faktor lain yang menjadi penyebab merebaknya penyakit kusta di Bangkalan. ${ }^{5}$ Faktor-faktor pencetus kusta di Bangkalan antara lain:

\section{a. Kondisi Geografis}

Secara umum geografis wilayah Madura adalah wilayah yang sangat panas, tergolong sebagai daerah kering dan kekurangan air sebagai sarana utama untuk menjaga kebersihan lingkungan dan diri. Secara umum masyarakat Madura, termasuk Kabupaten Bangkalan apabila musim kemarau sangat kekurangan air, dengan sangat minimnya persediaan air itu maka dapat dikatakan masyarakat Madura kekurangan air untuk sarana kebersihan. Apabila melihat data curah hujan, Kabupaten Bangkalan tergolong mempunyai curah hujan rata-rata yang sangat rendah yaitu sebesar 10,5 mm per tahun. Menurut klasifikasi Koppen, suatu daerah dikatakan daerah kering apabila curah hujan rata-ratanya di bawah $60 \mathrm{~mm}$ per tahun. Kondisi tersebut akan menyebabkan bakteri penyebab penyakit akan mudah berkembang karena tingkat kebersihan masyarakat sangat rendah yang disebabkan kekurangan air untuk sarana kebersihan. ${ }^{6}$

\section{b. Kepadatan penduduk}

Wilayah Bangkalan merupakan wilayah dengan tingkat kepadatan penduduk yang tinggi dibandingkan dengan wilayah Madura lainnya. Kepadatan penduduk yang tinggi serta kurangnya sarana kebersihan di daerah tersebut mengakibatkan lingkungan menjadi kumuh dan tidak sehat, sehingga mempercepat penyebaran bakteri penyebab kusta.

\section{c. Kurang Kesadaran Masyarakat}

Banyaknya masyarakat yang terkena penyakit kusta tetapi mereka enggan atau bahkan tidak mau berobat. Kesadaran yang sangat rendah akan pentingnya untuk berobat bagi penderita kusta di Bangkalan tersebut disebabkan oleh adanya pandangan bahwa penyakit kusta adalah penyakit Kutukan Tuhan. Pandangan masyarakat akan penyakit kusta sebagai penyakit kutukan tersebut tidak hanya terjadi di masyarakat Madura saja, tetapi hampir semua masyarakat di berbagai daerah pada awalnya juga menganggap bahwa penyakit kusta adalah penyakit kutukan. Pemikiran yang tidak logis ini menyebabkan banyak pasien kusta yang dikucilkan, sehingga pada akhirnya tidak mendapat pengobatan yang memadai. Kondisi inilah yang akan menyebabkan wabah penyakit Kusta semakin menyebar, karena tidak segera mendapatkan pengobatan yang benar. ${ }^{7}$

\section{d. Kontak Fisik}

Faktor lain yang menyebabkan terjadinya wabah penyakit kusta di Bangkalan adalah karena adanya kontak dengan pasien kusta yang serumah melalui udara. Kondisi tersebut juga sangat dipengaruhi oleh tingkat kekebalan tubuh atau antibodi tubuh anggota keluarga yang lain. Apabila tingkat kekebalan tubuh anggota keluarga rendah ditunjang dengan kondisi lingkungan yang kumuh, maka penyakit kusta akan mudah menular ke anggota keluarga yang lain. Penyebaran penyakit kusta juga dapat terjadi apabila di dalam suatu rumah ada orang yang

\footnotetext{
${ }^{5}$ Mededeelingen D.V.G. XXV (1936), hlm.53-64.

${ }^{6}$ Suci Rahmawati, Penyakit Kusta di Bangkalan Tahun 1934-1936, e-Journal, (Surabaya: UNESA,2010), hlm.14.

${ }^{7}$ Ibid
} 
mengidap penyakit kusta menular ke anggota keluarga yang lainnya. Jika ditinjau dari ilmu geografi merupakan prinsip interaksi. Prinsip interaksi adalah suatu hubungan yang saling terkait antara suatu gejala dengan gejala lainnya atau antara suatu faktor dengan faktor lainnya yang terjadi pada suatu ruang tertentu. Dalam hal ini dapat berupa hubungan antara faktor sosial dengan sosial, sosial dengan fisik. ${ }^{8}$ Penyebaran penyakit kusta melalui kontak serumah dalam prinsip interaksi merupakan hubungan antara faktor fisik dengan faktor fisik. Kabupaten Bangkalan merupakan daerah yang penduduknya sangat padat dengan lingkungan yang kumuh juga berperan dalam penyebaran penyakit kusta dan dalam hal ini jika ditinjau dari prinsip interaksi merupakan hubungan sosial dengan fisik.

\section{e. Kesalahan Diagnosis}

Kesalahan diagnosis disini bisa dikarenakan anggapan bahwa penyakit kusta adalah penyakit yang mudah menular dengan cara bersentuhan langsung dengan penderita kusta. Oleh karenanya masyarakat atau bahkan keluarga sendiri enggan untuk membantu penderita kusta untuk mendaoatkan pengobatan yang memadai. Kemudian kesalahan diagnosis dapat terjadi karena msaa kolonial penyakit kusta sangat mirip dengan penyakit frambusia atau patek. Penyakit kusta dan penyakit frambusia sama-sama menyerang kulit dan mempunyai penampakan yang sama. Kesalahan dalam pengobatan juga dapat memicu kegagalan penyembuhan pasien kusta. ${ }^{9}$

\section{Kebijakan Pemerintah Pemberantasan Kusta di Bangkalan}

Kebijakan pemerintah dalam mengatasi penyakit kusta di Hindia Belanda setelah tahun 1930 adalah dengan menerapkan hasil keputusan dalam konferensi Internasional di Bangkok. ${ }^{10}$ Kebijakan tersebut dilaksanakan mulai pada tahun 1932 di seluruh wilayah Hindia Belanda termasuk Bangkalan Madura. Kebijakan tersebut menyebutkan bahwa penderita kusta tidak harus diasingkan. Tahun 1932 Kepala Dinas Pemberantasan Penyakit Kusta, J.B. Sitanala memperkenalkan sistem tiga langkah penanganan pasien kusta yakni eksplorasi, pengobatan dan pemisahan (tanpa paksaan dan masih dalam lingkungan keluarga). Pada tahun 1934 pemerintah mulai mengadakan penggagasan propaganda kesehatan serta tindakan yang akan dilakukan untuk memberantas penyakit kusta khususnya di wilayah Bangkalan.

\section{Propaganda Kesehatan}

Pada tahun 1930-an awal, pemerintah membentuk beberapa kebijakan untuk menanggulangi perkembangan penyakit kusta merebak secara luas di wilayah Bangkalan. Upaya tersebut dilakukan karena usaha mandiri yang dilakukan oleh masyarakat di Bangkalan tidak membuahkan hasil. Upaya tersebut dimulai dengan sebuah program yang dinamakan

\footnotetext{
${ }^{8}$ Nursid Sumaatmadja, Studi Geografi: Suatu Pendekatan dan Analisis Ruang , (Bandung: Penerbit Alumni, 1981), hlm. 20.

${ }^{9}$ Ali Yusron, Evaluasi sistem Surveilans di Kabupaten Bangkalan, (Surabaya: Thesis Unair, 2009), hlm. 30.

${ }^{10}$ Overzicht aangaande de lepra bestrijding regentschap Bangkalan (residentie Madoera, Ned - Indie ) overgedrukt uit medische berichten 4 e jaargang 1940 No.5.
} 
dengan program propaganda kesehatan. Program propaganda kesehatan ini digagas oleh pemerintah pada tahun 1934. Program propaganda kesehatan ini berisi antara lain ajakan pemerintah kepada masyarakat di Bangkalan untuk berlaku hidup sehat, dilakukannya penyuluhan-penyuluhan bagaimana cara hidup sehat dan bersih serta ajakan untuk berobat ke klinik yang telah disediakan oleh pemerintah Hindia Belanda. ${ }^{11}$ Cara menjaga kebersihan diri dijelaskan oleh para mantri kesehatan dan juru rawat. Pengetahuan tersebut diberikan agar para penduduk mampu merawat badan secara mandiri. Selain itu, propaganda kesehatan yang digalakkan oleh pemerintah tersebut juga menerapkan finding case. Finding case adalah upaya pemerintah untuk mengetahui seberapa banyak masyarakat yang terjangkit kusta. Pada tahun 1936. Beberapa orang ditunjuk oleh pemerintah untuk ditunjuk sebagai pembantu kusta, mereka bekerja membantu pemerintah dalam menyebarkan propaganda kesehatan. setelah ditunjuk oleh pemerintah, mereka diberi pengetahuan seperti apa penyekit kusta tersebut, bagaimana mencegahnya dan bagaimana pengobatannya. Sampai awal tahun 1937, jumlah penderita kusta yang ditemukan di wilayah Bangkalan meningkat dari angka 294 ke angka 658. Hal ini dianggap bahwa finding case yang diterapkan oleh pemerintah menuai hasil. Setelah itu pemerintah menerapkan beberapa tindakan pemberantasan kusta.

\section{Tindakan Pemerintah}

Di Hindia Belanda penyakit kusta sudah mendapat perhatian oleh pemerintah sejak abad ke-17 berpusat di Batavia meskipun dalam hal ini merupakan minoritas. Pada masa itu, pengobatan kusta oleh pemerintah adalah dengan menggunakan minyak chaulmoogra atau yang pada saat itu sudah terlihat hasilnya. Minyak chaulmoogra didapat dari menyuling akar pohon dari keluarga Bixaceae hingga mengeluarkan minyak. ${ }^{12}$ Pemerintah Hindia Belanda pada masa itu masih belum tertarik sepenuhnya untuk menangani permasalahan yang ditimbulkan oleh kusta ini dan membiarkan orang yang menderita kusta begitu saja. Pemerintah baru mengambil tindakan pada tahun 1907, pada saat penyakit kusta benar-benar dianggap penyakit yang menular, namun masih tetap saja langkah-langkah untuk mencegah penyakit ini belum bisa dilaksanakan sepenuhnya.

Pada tahun 1917 pemerintah mewajibkan semua dokter untuk mempunyai pengetahuan tentang kusta, dan seandainya terdapat kasus kusta harus dilaporkan kepada pemerintah. Bagaimanapun juga, cara-cara yang ditempuh oleh pemerintah tersebut tidak menghasilkan apapun, kerjasama yang terjadi antara pemerintah dan dokter sangat sedikit bahkan hampir tidak ada. Pada tahun 1922, Inspektur Jendral Layanan Medis Sipil menyarankan agar pemerintah Hindia Belanda menarik peraturan yang dikeluarkan pada tahun 1917 tersebut, maka pada tahun tersebut dilakukan perhitungan rata-rata penderita kusta di Rumah Sakit Jiwa Penderita penyakit Kusta adalah 1441 orang, 171 berada di Pelantoengan, 75 berada di Donoredjo dan 85 berada di Semarang.

11 Sebelum tahun 1937, klinik kesehatan yang yang disediakan masih sedikit dan terletak di wilayah pusat desa. Setelah tahun 1937 poliklinik dibangun di hampir seluruh desa di Bangkalan karena kucuran dana "Dana Kesejahteraan Madura".

${ }^{12}$ Encyclopaedie Van Nederlandsch Indie, Tweede druk, 1918, Deel A-G, hlm.568. 
Pada tahun 1925, Inspektur Jendral Layanan Medis Sipil memperkenalkan RUU kusta pemaknaan baru yang memungkinkan dilaksanaknnya pemisahan wajib. RUU tersebut dimaksudkan agar menjadi dasar hukum, semacam induk peraturan yang mungkin disaat yang tepat bisa dilaksanakan. Pembentukan peraturan tersebut diperdebatkan oleh dewan rakyat dan peraturan tersebut gagal menjadi hukum. Hingga pada tahun 1930 komisi kusta dari liga bangsa-bangsa berkumpul di Bangkok untuk membahas masalah kusta, dimana majelis dari Hindia Belanda pun hadir. ${ }^{13}$ Hasil dari pertemuan tersebut adalah bahwa pemisahan ketat bisa dilakukan, namun hanya sebagai pilihan terakhir. Hal yang harus dilakukan adalah dengan cara melakukan pengobatan seefisien mungkin. Prinsip yang sama juga diadopsi pada saat konferensi kusta tahun 1931 di Manila, pemisahan wajib tidak praktis untuk 99\% penderita kusta di dunia.

Orang-orang pribumi zaman dahulu menggunakan tanaman obat untuk menjaga kesehatan maupun untuk pengobatan suatu penyakit yang disebut jamu atau ramuan tradisional. Ramuan tradisional tersebut sangat bermanfaat dan berguna bagi kehidupan manusia apabila digunakan sesuai anjuran. Bagi masyarakat, ramuan tradisional merupakan bagian dari budaya bangsa yang diwariskan turun-temurun dari leluhur. Ramuan Madura banyak di kenal dan dimanfaatkan vuntuk menjaga kesehatan dan mengobati penyakit.Pengetahuan tentang pembuatan ramuan Madura diwarisi secara turun temurun dalam suatu keluarga. Kebiasaan masyarakat Madura mengkonsumsi ramuan ataujamu telah menjadi kebiasaan turun-temurun dalam keluarga, terutama keluarga kerajaan dan keturunannya meminum ramuan sudah diperkenalkan pada anak atau keturunannya sejak dini dan lebih ditekankan kepada kaum perempuan untuk merawat tubuh dan memelihara kesehatan. Jamu atau ramuan Madura terutama dikenal sebagai ramuan untuk merawat tubuh atau menjaga serta memelihara kesehatan dan sebagian kecil sebagai pertolongan pertama pada pengobatan suatu penyakit. ${ }^{14}$

Bila dirasa belum sembuh maka mereka akan berobat ke ahli medis meskipun sebagai alternatif terakhir. Penyakit kusta merupakan salah satu penyakit yang bisa ditangani melalui pengobatan tradisional. Pengobatan tradisional untuk mengobati penyakit kusta telah dilakukan oleh masyarakat Bangkalan dengan menggunakan umbi bidara upas. Dari pengobatan tradisional yang telah dilakukan oleh masyarakat Bangkalan dalam mengobati penyakit kusta pada akhirnya mengharuskan memilih alternatif lain yakni pengobatan medis. Wabah penyakit kusta yang terjadi di Bangkalan semakin lama semakin meresahkan.Pada tahun 1897 pada konferensi di Berlin, T.Broes menyinggung bahwa Kabupaten Bangkalan adalah wilayah terbesar penyumbang penderita kusta di Pulau Madura, jika dibandingkan dengan 143 kasus yang ditemukan di Pamekasan dan 248 kasus kusta di Sampang, Bangkalan menyumbang 495 kasus penyakit kusta.

Dengan keadaan yang demikian perlu segera dilakukan tindakan cepat untuk menanggulangi wabah kusta tersebut. Untuk mengontrol penyakit kusta pemerintah juga

\footnotetext{
${ }^{13}$ Mededelingeen D.V.G XXV (1936), hlm.2.

${ }^{14}$ Suci Rachmawati, “Penyakit Kusta di Bangkalan Tahun 1934-1939”, e-Journal, (Surabaya, 2010), hlm.13.
} 
menambah empat mantri lulusan perawat dan enam pembantu kusta. ${ }^{15}$ Pengobatan tersebut meliputi pengobatan 294 pasien hidup penderita kusta yang dirawat selama tahun 1939 di seluruh kabupaten. Pengobatan tersebut tidak merata di semua tempat sehingga hanya ditempatkan pada 40 titik pengobatan di seluruh Kabupaten Bangkalan. Pertimbangan penentuan tempat yang digunakan sebagai titik pengobatan tersebut adalah berdasarkan letak lokasinya yang mudah terjangkau oleh masyarakat dan berdasarkan jumlah penderita kustanya cukup banyak.

Upaya persuasif pada masyarakat Bangkalan dalam menangani penyakit kusta yakni memberikan penyuluhan dan mengajak para penderita kusta kepada pasien kusta untuk secara rutin berobat ke klinik. Tentunya hal ini mendapat tanggapan dan reaksi masyarakat pribumi setempat. Masyarakat pribumi Bangkalan tentunya tidak serta merta percaya untuk mengikuti ajakan pemerintah kolonial dalam mengobati penyakit kusta.

Berkat kegigihan pemerintah kolonial yang serius dalam memberantas penyakit kusta akhirnya diterima oleh masyarakat pribumi Bangkalan. Hal ini tentunya juga didorong oleh pengobatan tradisional yang telah dilakukan oleh masyarakat pribumi yang belummenunjukkan hasilnya. Akhirnya kehadiran pasien kusta ke klinik pengobatan itu menunjukan hasil bahwa rata-rata $70 \%$ pasien kusta berobat ke klinik. ${ }^{16}$

Kesadaran diri untuk datang berobat ke klinik merupakan bentuk antusiasme penderita kusta dalam memerangi penyakit ini. Dalam hal ini untuk menunjang pengobatan maka didirikanlah 5 klinik rawat jalan dan sekitar 40 pusat kasual. Pada setiap kali kunjungan ada sekitar 9 pembantu perawat kusta dari 18 kecamatan yang datang untuk mengunjungi berbagai klinik. Tiap-tiap klinik rawat dan pusat kasual mendatangkan 4 pembantu kusta untuk menangani pasien Kusta Pengobatan secara medis penyakit kusta dilakukan dengan cara diberikan suntikan Chaulmoogra.

Dausse Collobiasse dan Obat Oral Chaulmograpils yang diminum tiga kali sehari. Chaulmoogra merupakan minyak murni yang disterilkan dan disuntikkan kepada pasien seminggu sekali. Minyak Chaulmoogra disuntikkan ke kulit dengan campuran chaulmoogra 60 cc dan Resorcin 4 gram. Pengobatan secara medis ini tentu membutuhkan biaya yang tidak sedikit, terutama untuk membeli obat-obatan injeksi tersebut. Pendanaan berkaitan dengan pemberantasan penyakit kusta di Madura khususnya di Kabupaten Bangkalan dibebankan pada anggaran dana yang ditanggung oleh pemerintah Kolonial Belanda. Biaya-biaya pengobatan ini dibebankan pada anggaran dana yang disebut "Fund Kesejahteraan Madura". ${ }^{17}$ Fund kesejahteraan Madura merupakan dana yang dibentuk oleh pemerintah Hindia-Belanda yang diprakarsai oleh Ratu Wilhelmina pada tahun 1937.

Pada tanggal 1937 dibentuklah Dana Kesejahteraan Madura oleh Ratu Wilhelmina yang mana pembiayaan ini dimaksudkan untuk kemajuan kesejahteraan masyarakat di Madura. Pada

\footnotetext{
${ }^{15}$ R.Md.Djoehana dalam Overzicht Aangande De Leprabestrijding In Het Regentschap Bangkalan, hlm. 2.

${ }^{16}$ Ibid.

${ }^{17}$ R.Md.Djoehana, op.cit., hlm. 2.
} 
kenyataannya, Dana Kesejahteraan Madura hanya berjalan lima tahun saja, hal ini disebabkan karena adanya invasi Jepang yang sudah diambang mata sehingga aktivitas-aktivitas dana ini terhenti pada akhir tahun $1941 .{ }^{18}$ Sampai dengan Desember tahun 1939 tercatat total terdapat 1.009 kasus penyakit kusta, dalam periode tahun 1934-1939, 277 penderita kusta meninggal, beberapa penderita dipindahkan ke tempat lain, hingga penderita kusta yang tersisa adalah 726 orang.

Para penderita kusta ditempatkan di leprozerieen yang terpisah dari masyarakat sekitar. Hal ini dimaksudkan untuk membatasi kontak antara yang sakit dengan yang sehat sehingga di harapkan mengurangi resiko penyebar infeksi. Tindakan isolasi ini tak lepas dari adanya "Dana Kesejahteraan Madura”. Dengan adanya Dana Kesejahteraan Madura maka didirikanlah 496 leprozerieen di Bangkalan untuk dipakai penderita kusta dalam pengobatan. Setiap leprozerieen dikenakan biaya sebesar 5 gulden untuk penderita kusta ${ }^{19}$.

Dana Kesejahteraan Madura telah mengeluarkan biaya sebesar 2000 gulden yang setara dengan pendirian leprozerieen yang dibangun oleh pejabat pemerintah sebanyak 400 unit. Kustadesa merupakan salah satu metode isolasi diri dan perlindungan diri yang berbasis pada masyarakat pribumi itu sendiri. Metode ini ditujukan bagi para penderita kusta untuk mendiami suatu kompleks terpencil. Namun hal ini terkadang sulit terlaksana. Di dalam desa tersebut para penderita kusta menikmati kebebasan penuh, mengatur urusan masyarakat mereka sendiri, memiliki kepala desa sendiri dan keperluan itu disediakan sebagian oleh orang kusta sendiri. Penerapan kusta-desa mempunyai dampak positif maupun negatif, disamping para penderita kusta yang dapat hidup dengan mandiri, namun mereka juga terisolasi dengan dunia luar, karena semua kebutuhan disediakan oleh para penderita kusta, maka kehidupan merekapun hanya dalam ruang lingkup kusta-desa itu sendiri.

\section{Kesimpulan}

Kondisi geografis Madura yang mendukung kurangnya ketersediaan air bersih, tingkat kepadatan penduduk yang tinggi, kurangnya kesadaran masyarakat dan kesalahan diagnosis merupakan faktor-faktor utama penyebab berkembangnya wabah Kusta di Madura terutama Bangkalan. Pemerintah Hindia Belanda berusaha menanggulangi penyakit kusta melalui propaganda kesehatan terutama di bidang higieni dan sanitasi serta kebijakan dalam pembangunan sarana kesehatan dan pengembangan pengobatan penyakit tersebut sehingga pada akhirnya wabah penyakit tersebut dapat berkurang dan teratasi.

\section{Daftar Pustaka}

Ali Yusron, Evaluasi sistem Surveilans di Kabupaten Bangkalan, (Surabaya: Thesis Unair, 2009)

\footnotetext{
${ }^{18}$ Huub De Jonge, Garam, Kekerasan dan Aduan Sapi.(Yogyakarta: Lkis,2000), hlm. 175.

${ }^{19}$ R.Md.Djoehana.,op.cit.hlm.2.
} 
Baha'uddin, “Dari Mantri hingga Dokter Jawa: Studi Kebijakan Pemerintah Kolonial dalam Penanganan Penyakit Cacar Di Jawa Abad XIX-XX”, Humaniora. Vol.18 No.3 (Yogyakarta, 2006)

Boomgaard, Peter, “Syphilis, Gonorrhoea, Leprosy and Yaws in Indonesian Archipelago, 1500-1950”. MANUSYA: Jurnal of Humanities, Special Issue No.14.2007

Encyclopaedie Van Nederlandsch Indie, Tweede druk, 1918, Deel A-G

Huub De Jonge, Garam, Kekerasan dan Aduan Sapi.(Yogyakarta: Lkis,2000)

Marwali Harahap, Ilmu Penyakit Kulit, (Jakarta: Hipokrates, 1998)

Mededeelingen D.V.G. XXV (1936)

Muh. Syamsuddin, Agama, Migrasi dan Orang Madura. Aplikasia, Jurnal Aplikasia Ilmu-ilmu Agama, Vol VIII, No.2, Desember (Yogyakarta:UIN,2007)

Nursid Sumaatmadja, Studi Geografi: Suatu Pendekatan dan Analisis Ruang , (Bandung: Penerbit Alumni, 1981)

Overzicht aangaande de lepra bestrijding regentschap Bangkalan (residentie Madoera, Ned - Indie ) overgedrukt uit medische berichten 4 e jaargang 1940 No.5.

R.Md. Djoehana dalam Overzicht Aangande De Leprabestrijding In Het Regentschap Bangkalan

Suci Rachmawati, “Penyakit Kusta di Bangkalan Tahun 1934-1939”, e-Journal, (Surabaya, 2010) 